Pesq. Vet. Bras. 36(7):591-594, julho 2016 DOI: $10.1590 / \mathrm{S} 0100-736 \mathrm{X} 2016000700005$

\title{
Identification and characterization of Aspergillus fumigatus isolates from broilers ${ }^{1}$
}

\author{
Andréia Spanamberg ${ }^{2,3 *}$, Laerte Ferreiro², Gustavo Machado ${ }^{3,4}$, Cibele Floriano \\ Fraga $^{2,3}$ and Ricardo Araujo ${ }^{5}$
}

\begin{abstract}
Spanamberg A., Ferreiro L., Machado G., Fraga C.F. \& Araujo R. 2016. Identification and characterization of Aspergillus fumigatus isolates from broilers. Pesquisa Veterinária Brasileira 36(7):591-594. Laboratório de Micologia, Faculdade de Veterinária, Universidade Federal do Rio Grande do Sul, Av. Bento Gonçalves 9090, Porto Alegre, RS 91540-000, Brazil. E-mail: spanamberg.ad@gmail.com

Aspergillosis is one of the main causes of mortality in birds. The pulmonary system is most frequently affected, with lesions observed in the air sacs and lungs of a wide variety of bird species. The aim of this study was to confirm by molecular methods the identification and the genetic diversity of Aspergillus fumigatus isolates of lung's samples from healthy broilers (Galus galus domesticus). Forty-four (9.5\%) isolates of lung's samples were confirmed as A. fumigatus by polymerase chain reaction (PCR) multiplex (amplification of $\beta$-tub and rodA gene fragments). Microsatellite typing for $A$. fumigatus was used to analyse all avian isolates. Among them, 40 genotypes (90.9\%) were observed only one time. The results showed a high variability and multiple genotypes of de $A$. fumigatus collected from lung's samples of broilers.
\end{abstract}

INDEX TERMS: Aspergillus fumigatus, broilers, molecular identification, multiplex PCR, genotyping.

RESUMO-- [Identificação e caracterização de Aspergillus fumigatus isolados de frangos de corte.] Aspergilose é uma das principais causas de mortalidade em aves. O sistema pulmonar de uma grande variedade de espécies de aves é o mais frequentemente afetado, com lesões nos sacos aéreos e pulmões. Objetivou-se confirmar por métodos moleculares a identificação e a diversidade genética de Aspergillus fumigatus isolados de amostras pulmonares de frangos de corte sadios (Galus galus domesticus). Quarenta e quatro $(9,5 \%)$ isolados foram confirmados como A. fumigatus através de reação em cadeia da polimerase (PCR) multiplex (amplificação de fragmentos dos genes $\beta$-tub e $\operatorname{rodA}$ ).

\footnotetext{
${ }^{1}$ Received on June 24, 2015.

Accepted for publication on April 19, 2016.

${ }^{2}$ Setor de Micologia, Faculdade de Veterinária (FaVet), Universidade Federal do Rio Grande do Sul (UFRGS), Avenida Bento Gonçalves 9090, Porto Alegre, RS 91540-000, Brazil. *Corresponding author: spanamberg.ad@ gmail.com

${ }^{3}$ Programa de Pós-Graduação em Ciências Veterinárias (PPGCV), UFRGS, Av. Bento Gonçalves 9090, Porto Alegre, RS 91540-000.

${ }^{4}$ Laboratório de Epidemiologia Veterinária, FaVet-UFRGS, Av. Bento Gonçalves 9090, Porto Alegre, RS 91540-000.

${ }^{5}$ Institute of Molecular Pathology and Immunology (IPATIMUP), Universidade do Porto, Porto, Portugal.
}

Todos isolados foram tipificados, sendo quarenta $(90,9 \%)$ observados apenas uma vez. Os resultados mostram uma alta variabilidade e múltiplos genótipos de $A$. fumigatus obtidos de amostras pulmonares de frangos, de corte.

TERMOS DE INDEXAÇÃO: Aspergillus fumigatus, frangos de corte, identificação molecular, PCR multiplex, genotipagem.

\section{INTRODUCTION}

Aspergillosis is the most common mycotic disease in birds. The pulmonary system is most frequently affected with lesions observed in the air sacs and lungs of a wide variety of bird species, which are hosts potentially susceptible to infections by Aspergillus spp. (Charlton et al. 2008). Clinical cases of aspergillosis have already been diagnosed in chickens, turkeys, ostriches, rheas, penguins, geese (Carrasco et al. 2001, Lair-Fulleringer et al. 2003, Copetti et al. 2004, Paixão et al. 2004, Ziólkowska \& Tokarzewski 2007, Islan et al. 2009, Ceolin et al. 2012) as well as in many other species (Cray et al. 2009, Spanamberg et al. 2012). The presence of conidia in the respiratory system may cause only colonization, which allows the fungal isolation from the lung tissue (Arné et al. 2011). Aspergillus fumigatus is the major aetiological agent responsible and is reported in the Brazilian 
veterinary literature (Copetti et al. 2004, Xavier et al. 2006, Spanamberg et al. 2012, 2013).

Mycological identification frequently rely only on conventional cultivable methods on Sabouraud Dextrose Agar and Malt Extract Agar. Molecular methods for the identification is recommended since many species macroscopic and microscopically similar to this species have been described belonging to Section Fumigati, which sometimes cause difficulties to the correct diagnosis (Balajee et al. 2005, Serrano et al. 2011). Microsatellites are the genetic markers of choice for studying A. fumigatus molecular epidemiology since a microsatellite-based multiplex PCR has been proved to be specific, highly reproducible, fast and economic way of targeting molecular identification of $A$. $f u$ migatus in human clinical laboratories (Araujo et al. 2009, Araujo et al. 2012).

Different genotyping methods have been developed and employed (Vanhee et al. 2008, Thierry et al. 2010, Van Waeyenberghe et al. 2011). In Brazil, there is a lack of molecular data about epidemiological analyses. The aim of this study was to confirm by molecular methods the identification and verify the genetic diversity of $A$. fumigatus isolates of lung's samples from Brazilian broilers.

\section{MATERIALS AND METHODS}

Collection of samples. The samples $(n=464)$ came from 56 flocks localized in the Vale do Taquari - State of Rio Grande do Sul, RS, Brazil. Lungs were collected from healthy broilers (Galus galus domesticus), directly from the slaughter line of a slaughterhouse of the State of Rio Grande do Sul, Brazil and kept under refrigeration $\left(4^{\circ} \mathrm{C}\right)$. The evaluation and condemnation of carcasses were performed by the personnel from the sanitary inspection department. All animal welfare requirements in force were observed in the slaughter process, in accordance with the respective inspection department.

Fungal strains and culture conditions. Initially, lungs samples were cultured onto Sabouraud Dextrose and Malt Extract Agar plates. After 7 days of incubation $\left(37^{\circ}\right.$ to $\left.40^{\circ} \mathrm{C}\right)$ the colonies of Aspergillus were subcultured onto Czapeck-Dox Agar for final macro and microscopical identification. Individual colonies presenting macro and microscopic features of $A$. fumigatus were selected and the conidia are kept in a saline solution stored at $4^{\circ} \mathrm{C}$.

DNA extraction. For this purpose, isolates were subcultured onto a new Petri dish with Malt Extract Agar $\left(37^{\circ}-40^{\circ} \mathrm{C} / 5\right.$ days). A Qiagen DNeasy ${ }^{\circledR}$ plant mini DNA extraction kit protocol was used to extract DNA from the conidia. Fungal DNA was frozen at $-20^{\circ} \mathrm{C}$.

Molecular identification of Aspergillus fumigatus. Molecular identification was performed using specific primers for identification of Aspergillus section Fumigati and A. fumigatus (Table 1) (Serrano et al. 2011). Multiplex PCR amplification was performed in a $5 \mu$ l final volume containing $1 \mu \mathrm{L}$ of genomic DNA (1-5ng/ $\mu \mathrm{L}$ ), $2.5 \mu \mathrm{L}$ of $2 \mathrm{x}$ Qiagen multiplex PCR master mix (Qiagen, Hilden, Germany) and $0.5 \mu \mathrm{L}$ of each primer (for a $0.2 \mu \mathrm{M}$ final concentration of each primer). After a pre-incubation at $95^{\circ} \mathrm{C}$ for $15 \mathrm{~min}$, the amplification was performed for a total of 35 cycles as follows: denaturation at $94^{\circ} \mathrm{C}$ for $30 \mathrm{~s}$, annealing at $69^{\circ} \mathrm{C}$ for $90 \mathrm{~s}$, extension at $72^{\circ} \mathrm{C}$ for $1 \mathrm{~min}$, and a final extension step of $10 \mathrm{~min}$ at $72^{\circ} \mathrm{C}$. Amplicons were visualized following electrophoresis in polyacrylamide gels with a standard DNA silver staining method (Qu L et al. 2005).

Microsatellite multiplex for A. fumigatus genotyping. Microsatellite PCR multiplex was performed according to previously
Table 1. Primers for molecular identification of $\boldsymbol{A}$. fumigatus

\begin{tabular}{lllc}
\hline Aspergillus seção & b-tubulin & F & AGGCAGACCATCTCTGGTGAG \\
Fumigati & & R & TCGGAGGAGCCATTGTAGC \\
& Rodlet A & F & CCAGGCTCAGCTCTCTTGCT \\
A. fumigatus & & $\mathrm{R}$ & CCACCACCGATGAGGTTCTT \\
& b-tubulin & $\mathrm{F}$ & TGACGGGTGATTGGGATCTC \\
& & $\mathrm{R}$ & CGTCCGCTTCTTCCTTGTTT \\
& Rodlet A & $\mathrm{F}$ & ACATTGACGAGGGCATCCTT \\
& & $\mathrm{R}$ & ATGAGGGAACCGCTCTGATG
\end{tabular}

selected primers located in different chromosomes (Araujo et al. 2009). The PCRs were performed in $5 \mu \mathrm{L}$ final volume, with $0.5 \mu \mathrm{L}$ of genomic DNA (1-5ng/ $\mu \mathrm{L}), 2.5 \mu \mathrm{L}$ of $2 \times$ Qiagen multiplex PCR master mixes (Qiagen, Hilden,Germany) and $0.5 \mu \mathrm{L}$ of a mix of eight primer pairs, at $2 \mu \mathrm{M}$ concentration. After a $95^{\circ} \mathrm{C}$ preincubation step of $15 \mathrm{~min}$, PCRs were performed for a total of 35 cycles, using the following conditions: denaturation at $94^{\circ} \mathrm{C}$ for 30 $\mathrm{s}$, annealing at $60^{\circ} \mathrm{C}$ for $60 \mathrm{~s}$ and extension at $72^{\circ} \mathrm{C}$ for $2 \mathrm{~min}$; with a final extension step of $10 \mathrm{~min}$ at $72^{\circ} \mathrm{C}$. The internal size standard GeneScan 500 LIZ (Applied Biosystems) $(0.4 \mu \mathrm{L})$ and HiDiformamide (Applied Biosystems) $(10 \mu \mathrm{L})$ were added to the PCR-amplified products and run in an ABI PRISM 3100genetic analyser 16-capillary electrophoresis system (Applied Biosystems). Fragment size was performed automatically using Genemapper software 4.0 (Applied Bio systems). The reference $A$. fumigatus strain ATCC 46645 was genotyped in standard conditions showing a final electrophoretic profile of eight expected peaks corresponding to each microsatellite locus (Araujo et al. 2012).

Data and statistical analyses. Data sheets and procedures adopted (records of days of culture samples, manipulation of isolates and DNA extraction) for control of each culture were revised after electrophoresis results in order to exclude identical isolates originated from the same sample or possible laboratory contamination.

The Simpson index of diversity (1-D) ranges between 0 (minimum diversity/similarity) and 1 (maximum diversity/similarity), the greater the value of diversity index, greater in the richness and abundance of the species/gene. It was computed for all dominated loci index with all markers, calculated according to Hunter and Gaston (1988), using the R package untb (Hankin 2007).

Cluster analysis was performed with the statistiXL program (http://www.statistixl.com/default.aspx) using Euclidean distances without rescaling the data with the linkage-type unweighted pair-group average method (UPGMA).

\section{RESULTS}

Forty-four (9.5\%) lung's samples were positives for mycological isolation of fungal isolates belonging to Aspergillus section Fumigati (macro and microscopical identification). No fungal growth in the remaining $420(90.5 \%)$ samples. All isolates were obtained from healthy broilers.

All isolates (44) were confirmed as Aspergillus fumigatus following the amplification of $\beta$-tub and rodA gene fragments and gel electrophoresis.

Multiplex PCR was successfully performed on all isolates. The complete profile with eight peaks was found, confirming the A. fumigatus specificity. The result of UPGMA analysis of 44 Aspergillus fumigatus genotypes based on the number of repeats obtained following microsatellite multiplex genotyping (8 microsatellites located in 7 different chromosomes were considered) (Fig.1). Among this group, 40 genotypes $(90.9 \%)$ were unique and four genotypes 
were found twice. The cophenetic correlation coefficient was $0.901(\mathrm{P}<0.001)$, indicating a very strong correlation with the represented distances and the final dendrogram. The Simpson's index of diversity (D) for the avian isolates was calculated to be 0.86 . The results allowed the identification of four clusters (Fig.1), accounting for 1, 2, 15 and 26 isolates. None of the identified clusters (A, B, C and D) could be associated with the geographic location of the studied flocks or the date of collection.

\section{DISCUSSION}

Aspergillus species are ubiquitous filamentous fungi widely distributed in the environment and Aspergillus fumigatus is considered as a major respiratory pathogen for birds. Other species like A. flavus, A. niger, A. nidulans and A. terreus may also be isolated from avian cases of aspergillosis (sometimes in mixed infections) but much less frequently than A. fumigatus (Tell 2005, Arné et al. 2011). Species

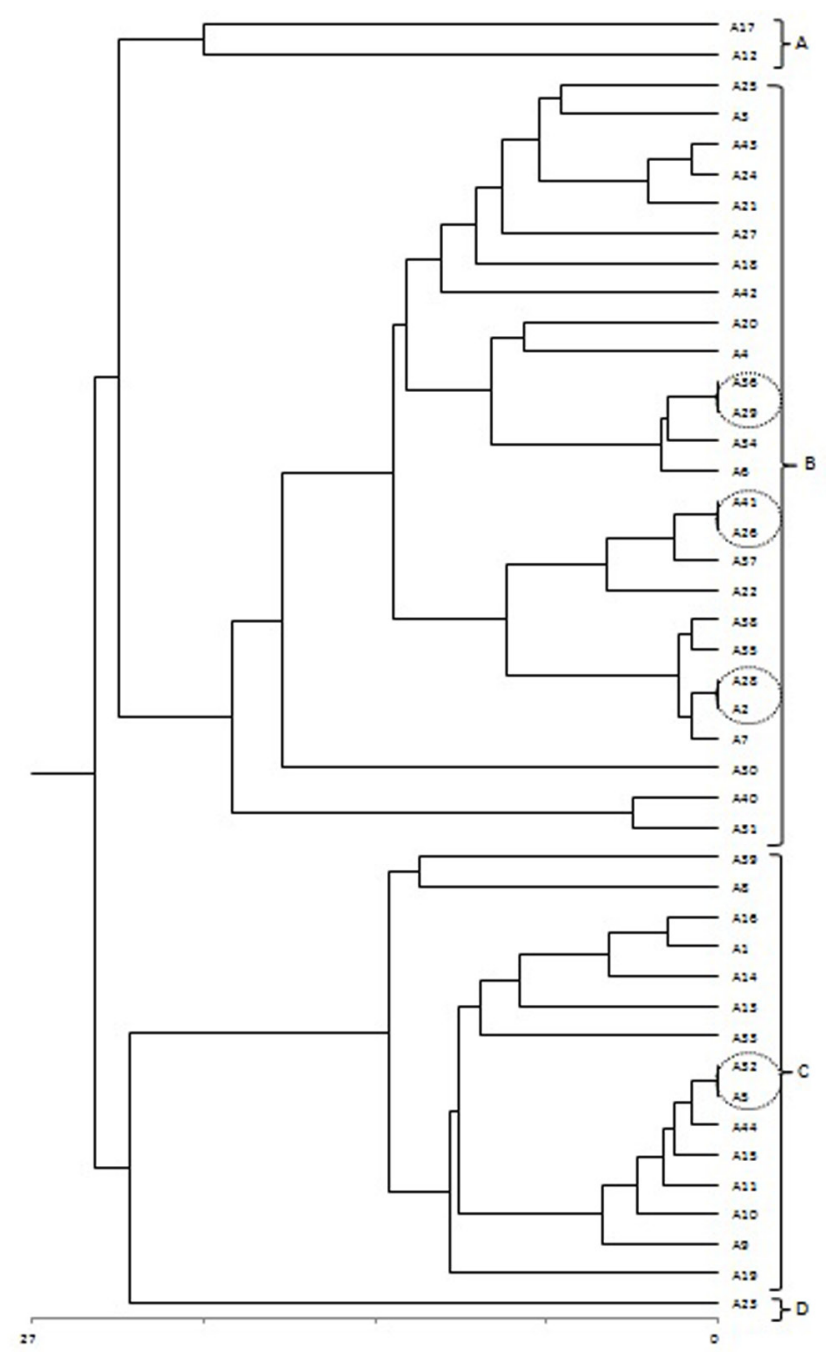

Fig.1. The result of UPGMA analysis of 44 Aspergillus fumigatus genotypes based on the number of repeats obtained following microsatellite multiplex genotyping ( 8 microsatellites located in 7 different chromosomes). Clusters A, B C and D were identified. Circled isolates represent the isolates with similar genotype (4 groups). within the section Fumigati have been described as human pathogens, particularly A. lentulus, A. viridinutans, Neosartorya pseudofischeri and N. udagawae (Serrano et al. 2011). Based on these reports, species within the section Fumigati may be involved in bird's diseases or may be present in the lungs of healthy birds. All isolates in our study were A. fumigatus which were obtained from healthy birds. This finding it is in agreement with the literature, since due to ubiquitous distribution of $A$. fumigatus, all poultry flocks are inhaling airborne conidia during the rearing or laying period (Kunkle 2003), and so, its isolation from lungs of healthy birds is considered quite frequent (Arné et al. 2011).

High genotypic diversity indices have been described among clinical and environmental isolates of A. fumigatus, usually as the result of studying outbreaks at human hospitals. Conidia are easily disseminated (Latgé 1999, Pasqualloto 2009), factor that contributes for an high strain diversity of isolates. Consequently, it is expected a high genetic diversity of strains inhaled by the birds. In this study, 44 isolates were genotyping, showing a high genetic diversity. Actually, the strains typed represent only a small part of the fungal population potentially inhaled by the birds, and considering that environmental or clinical strains have the potential to cause disease in susceptible birds, our results are important to know if only one genotype could be prevalent in the current system of commercial poultry.

Molecular typing studies showed that there was a high variability among avian isolates and multiple genotypes recovered from healthy and disease birds (Lair-Fulleringer et al. 2003, Olias et al. 2009). Van Waeyenberghe et al. (2011) obtained ( 57 genotypes of 65 isolates; $87.7 \%$ ). On the other hand, Alvarez-Perez et al. (2010) reported 13 (39.4\%) distinct genotypes in 33 isolates obtained from five diseased birds, and Lair-Fulleringer et al. (2003) reported 17 (15\%) distinct genotypes in 114 isolates from healthy and diseased turkeys. Our results could be explained due to the use of eight microsatellite markers combined in a single PCR multiplex assay available for $A$. fumigatus genotyping.

No association was found between isolation date or location of flocks and the genetic clusters identified on the fungal population, confirming a large dispersion of $A$. fumigatus conidia in the regional environment. Identical genotypes can occur by chance in unrelated isolates, a probable explanation for this result is that the birds were exposure to a common source of mycoflora. The hatchery environment could be contaminated by Aspergillus - the conidia can easily enter the air handling unit and ventilation system. Moreover, the birds could be contaminated when exposed to a common source of poultry houses's environment and feedstuffs, including roughages and concentrates, which is in agreement with literature (Charlton et al. 2008, Arné et al. 2011). The climate, temperature and humidity are ideal for the propagation of Aspergillus, especially when organic matter (debris) has accumulated.

\section{CONCLUSÃO}

Our results showed that occurs a high variability isolates and multiple genotypes among avian isolates. It is crucial a minimization of stress-related issues due to avian manage- 
ment and transport, which are complementary conditions that enhance the development of opportunistic mycoses such as aspergillosis. Furthermore, genotyping studies on fungal populations may provide opportunity to compare genetic diversity within and among clinical and environmental isolates from broilers.

Acknowledgements.- Financial support was received from Fundação de Amparo à Pesquisa do Estado do Rio Grande do Sul (FAPERGS), Conselho Nacional de Pesquisa (CNPq) and by Ipatumup. RA is supported by Fundação para a Ciência e a Tecnologia (FCT) Ciência 2007 and by the European Social Fund. Ipatimup is an Associate Laboratory of the Portuguese Ministry of Science, Technology and Higher Education and is partially supported by FCT.

\section{REFERENCES}

Alvarez-Perez S., Mateos A., Dominguez L., Martinez-Nevado E., Blanco J.L. \& Garcia M.E. 2010. Polyclonal Aspergillus fumigatus infection in captive penguins. Vet. Microbiol. 144:444-449.

Araujo R., Amorim A. \& Gusmão L. 2012. Diversity of microsatellites within Aspergillus section Fumigati. BMC Microbiol. 12:154.

Araujo R., Pina-Vaz C., Rodrigues A.G., Amorim A. \& Gusmão L. 2009. Simple and highly discriminatory microsatellite-based multiplex PCR for Aspergillus fumigatus strain typing. Clin. Microbiol. Infect. 15:260-266.

Arné P., Thierry S., Wang D., Deville M., Le Loc'h G., Desoutter A., Féménia F., Nieguitsila A., Huang W., Chermette R. \& Guillot J. 2011. Aspergillus fumigatus in Poultry. Int. J. Microbiol. Article ID 746356, doi:10.1155/2011/746356. 14p.

Balajee S.A., Gribskov J., Brandt M., Ito J., Fothergill A. \& Marr K.A. 2005. Mistaken identity: Neosartorya pseudofischeri and its anamorph masquerading as Aspergillus fumigatus. J. Clin. Microbiol. 43:5996-5999.

Carrasco L., Lima J.S., Halfen D.C., Salguero F.J., Sanchez-Cordon P. \& Becker G. 2001. Systemic aspergillosis in an oiled magallanic penguin (Spheniscus magellanicus). J. Vet. Med. B, Infect. Dis. Vet. Public Health 48:551-554.

Ceolin L.V., Flores F., Oliveira I.M.C., Lovato M., Galiza G.J.N., Kommers G.D., Risso N. \& Santurio J.M. 2012. Macroscopic and Microscopic Diagnosis of Aspergillosis in Poultry. Acta Scient. Vet. 40:1061.

Charlton B.R., Chin R.P. \& Barnes H.J. 2008. Fungal Infections, p.989-1001. In: Saif Y.M., Fadly A.M., Glisson J.R., McDougald L.R., Nolan L.K. \& Swayne D.E. (Eds), Diseases of Poultry. Blackwell Publishing, Ames, Iowa.

Copetti M.V., Segabinazi S.D., Flores M.L., Alves S.H. \& Santurio J.M. 2004. Pulmonary aspergillosis outbreak in Rhea americana in Southern Brazil. Mycopathologia 157:269-271.

Cray C., Watson T. \& Arheart K. 2009. Serosurvey and diagnostic application of antibody titers to Aspergillus in avian species. Avian Dis. 53:491-494.

Hankin R.K.S. 2007. Introducing untb, an R package for simulating ecological drift under the unified neutral theory of Biodiversity. J. Stat. Softw. 22:1-15.

Hunter P.R. \& Gaston M.A. 1988. Numerical index of the discriminatory ability of typing systems: an application of Simpson's index of diversity. J. Clin. Microbiol. 26(11):2465-6.
Islan M.N., Rashid M.H., Juli M.S.B., Rima U.K. \& Khatun M. 2009. Pneumomycosis in chickens: clinical, pathological and therapeutical investigation. Int. J. Sustain. Crop Prod. 4:16-21.

Kunkle R.A. 2003. Aspergillosis, 883-895. In: Saif YM (Ed.), Diseases of Poultry. Iowa State University Press, Amesd.

Lair-Fulleringer S., Guillot J., Desterke C., Seguin D., Warin S., Bezille A., Chermette R. \& Bretagne S. 2003. Differentiation between Isolates of Aspergillus fumigatus from Breeding Turkeys and Their Environment by Genotyping with Microsatellite Markers. J. Clin. Microbiol. 41:1798-1800.

Latgé J.P. 1999. Aspergillus fumigatus and Aspergillosis. Clin. Microbiol. Rev. 12:310-350.

Olias P., Lierz M., Hafez H.M., Jacobsen I.D. \& Gruber A.D. 2009. Microsatellite genotyping and virulence assessment of Aspergillus fumigatus isolates from white stork nestlings and their environment. J. Comp. Pathol. 141:266-266.

Paixão T.A., Nascimento E.F., Parra P.N.S. \& Santos R.L. 2004. Aspergilose em avestruz (Struthio camelus) no Brasil. Ciênc. Rural. 34:573-576.

Pasqualloto A.C. 2009. Differences in pathogenicity and clinical syndromes due to Aspergillus fumigatus and Aspergillus flavus. Med. Mycol. 47:S261-S270.

Qu L., Li X., Wu G. \& Yang N. 2005. Efficient and sensitive method of DNA silver staining in polyacrylamide gels . Electrophoresis 26:99-101.

Serrano R., Gusmão L., Amorim A. \& Araujo R. 2011. Rapid identification of Aspergillus fumigatus within the section Fumigati. BMC Microbiol. 11: 82.

Spanamberg A., Machado G., Casagrande R.A., Sales G.M., Fraga C.F., Corbellini L.G., Driemeier D. \& Ferreiro L. 2013. Aspergillus fumigatus from normal and condemned carcasses with airsacculitis in commercial poultry. Pesq. Vet. Bras. 33:1071-1075.

Spanamberg A., Casagrande R.A., Ferreiro L., Rolim V.M., Souza S.O., Gonçalves I.C.M., Oliveira L.G.S., Wouters F., Wouters A.T.B., Fontana C.S. \& Driemeier D. 2012. Aspergillosis in green-winged saltators (Saltator similis) participants in bird singing competitions. Acta Scient. Vet. 40:1089.

Tell L.A. 2005. Aspergillosis in mammals and birds: impact on veterinary medicine. Med. Mycol. 43:71-73.

Thierry S., Wang D., Arné P., Deville M., De Bruin B., Nieguitsila A., Pourcel C., Laroucau K., Chermette R., Huang W., Botterel F. \& Guillot J. 2010. Multiple-locus variable-number tandem repeat analysis for molecular typing of Aspergillus fumigatus. BMC Microbiol. 10:315.

Van Waeyenberghe L., Pasmans F., Beernaert L.A., Haesebrouck F., Vercammen F., Verstappen F., Dorrestein G.M., Klaassen C.H. \& Martel A. 2011. Microsatellite typing of avian clinical and environmental isolates of $\mathrm{As}$ pergillus fumigatus. Avian Pathol. 40:73-77.

Vanhee L.M.E., Symoens F., Nelis H.J. \& Coenyea T. 2008. Microsatellite typing of Aspergillus fumigatus isolates recovered from deep organ samples of patients with invasive aspergillosis. Diagn. Micr. Infec. Dis. 62:96-98.

Xavier M.O., Leite A.T.M. \& Soares M.P. 2006. Aspergilose em pingüim-de-magalhães (Spheniscus magellanicus): relato de caso. Vet. Zootec. 13:28-32.

Ziólkowska G. \& Tokarzewski S. 2007. Occurrence of moulds in reproductive goose flocks in southern-eastern Poland. Bull. Vet. Inst. Pulawy 51:553-561. 